\title{
Economics of Higher Education: Research Publications in English in Canada, 1971 to $1981^{*}$
}

\author{
DAVID STAGER $\dagger$
}

\begin{abstract}
Research in the economics of education declined from the early 1970s to the end of the decade. American studies in the early 1960s had stimulated work on the contribution of education to economic growth and earnings differentials, but rapid expansion in post-secondary education led to declining relative earnings of graduates and a disillusionment with investment in higher education. In Canada, renegotiations of the Fiscal Arrangements Act in 1971-72 simply extended the 1967 provisions and dampened further interest in alternative financing arrangements. Topics researched in the 1970s in Canada were similar to those examined elsewhere: rates of return, institutional costs and efficiency, demand for education, income redistribution, alternative financing, manpower planning. Current work emphasizes enrolment flows. Future research should be directed to the demand for education and the relationship between education and earnings.
\end{abstract}

\section{RESUME}

La recherche dans le domaine de l'économie de l'éducation a subi un déclin dans les années 1970. Au début des années 60, plusieurs études américaines avaient stimulé les travaux démontrant la contribution de l'éducation à la croissance économique et aux différences de revenus, mais l'expansion rapide del'éducation supérieure a mené au rétrécissement relatif des écarts de revenus et au désenchantement envers l'éducation postsecondaire comme investissement. Au Canada, les renégociations de l'arrangement fiscal entre les gouvernements fédéral et provinciaux conclues en 1971-72 ne firent que prolonger les ententes de 1967 et éteindre l'intérêt pour la recherche de d'autres alternatives fiscales. Les thèmes de recherche étudiés au Canada dans les années 70 furent essentiellement les mêmes que ceux examinés ailleurs: taux de rendement, coût-bénéfice, demande pour l'éducation,

\footnotetext{
* I am grateful for comments from J. Schaafsma, O. Mehmet, W. Hettich, and anonymous referees.

† Department of Political Economy, University of Toronto
} 
redistribution du revenu, alternatives de financement et main-d'oeuvre planifiée. Les thèmes courants portent principalement sur les modèles de flux et devraient dans le futur s'orienter vers la demande pour l'éducation et la relation entre le niveau de scolarité et le revenu.

This paper attempts to include work which was published, in English since January 1971, dealing with the economics of post-secondary education (but generally excluding university research) and which was done in or about Canada. Definitions of "research" and "economics" are not easily stated. The bibliography which is the focus of this paper includes items ranging from political tracts to theoretical dissertations. The former were included only if they seemed to have a substantial influence on research activity. "Economics" has been defined as "whatever economists do". ${ }^{1}$ Papers or reports by persons generally regarded as economists have been included, but so have papers from other disciplines if the work concerned resource allocation, financing, or related labour markets.

Items will have been missed that ought to have been included. For this I apologize to the readers, and especially to the omitted authors. Some items that have been included will be questioned, but this implicitly indicates the paucity of bona fide research since a strict criterion of research would have resulted in a very short list. A thorough search of the literature was not possible; indeed it is not clear what the boundaries might be. I have reviewed the AUCC Inventory of Research into Higher Education, the published and draft Bibliographies of Higher Education in Canada by Robin Harris and his colleagues, the Canadian Journal of Economics, Canadian Journal of Higher Education, Journal of Canadian Studies, Canadian Tax Journal, Canadian Public Policy, and Higher Education. ${ }^{2}$ Also included are several reports prepared for royal commissions, task forces, and other government departments and agencies.

The paper first examines the decline in research activity and publications in this field, then outlines the topics which were researched, mentions some current work, and finally suggests areas to be emphasized in future research.

\section{The Decline in Research Activity}

The first and major impression from this bibliographic review is that most of the research was done at the beginning of the decade. Moreover, much of the work published in 1971 to 1973 had been initiated in 1968 to 1970 . There has been a minor rekindling of interest in some topics in 1978 to 1980, but these seem to be isolated efforts or by-products of other work.

Second, one observes a major shortfall between reported research activity and the published results. ${ }^{3}$ This occurs partly because the research is undertaken for or by a government department with limited distribution of the work and when the findings are of limited interest or relevance. Much of the research in this 
field has been sponsored by governments or agencies, but in the earlier years there was a predominance of councils, commissions, and task forces who were interested in having their studies made widely available to the public.

Why was there so much more research activity early in the decade? There seem to be a number of related reasons. Education had been identified by Edward Denison in the early 1960s as the major source of economic growth; T.W. Schultz incorporated this in the notion of education as an investment good, or as a form of human capital; and Gary Becker produced a theory of human capital. ${ }^{4}$ The pioneering work by Denison, Schultz, and Becker resulted in numerous doctoral dissertations in this area as graduate students and their supervisors recognized the need to test and refine the theoretical framework. Their focus was directly on education as the major, or sole variable in explaining economic growth of earnings differentials. Since then, the human capital model has lost the glow of novelty and has been challenged by several authors who argue that the economic importance of education is overestimated. ${ }^{5}$ Education now tends to be treated as only one among several explanatory variables in a more general theory of income determination. ${ }^{6}$

The earlier theoretical research also coincided with the rapid expansion and diversification of the post-secondary system in the mid-1960s. Governments were looking for assistance in their planning and budgeting for post-secondary education and consequently were willing to support related empirical research. Then the labour market for post-secondary graduates caused some alarm. The supply of highly qualified manpower had increased more rapidly than did demand in the late 1960s. Since wages and salaries do not adjust very quickly to such major market disturbances, new graduates discovered they could not obtain the kind of employment they expected, or at the expected salary level. Governments were then disappointed and perhaps embarrassed by the economic analysis that had just so recently provided a rationale for expansion of the postsecondary system. There was also at this time (1971 to 1975) a sharp increase in public support for welfare plans, health services, and housing, followed by the energy crisis and rapid inflation, and then wage and price controls. Higher education was pushed down on the public agenda and was severely squeezed in the public budget.

These events occurred more or less simultaneously in all advanced economies, but in Canada there was an important additional factor contributing to the earlier interests and later decline. Preparation for federal-provincial negotiation of a 1972 revision of the Fiscal Arrangements Act (by which the federal government transferred funds to the provinces for post-secondary education) had stimulated much of the research in 1970 and 1971. The Council of (Provincial) Ministers of Education sponsored several studies ${ }^{7}$ while the Economic Council of Canada undertook similar studies indirectly on behalf of the federal government. ${ }^{8}$ By 1970 the federal government was seeking a method to constrain its contribution and the provinces were anxious to maintain both the federal revenue and provincial autonomy in education. The basic provisions of the 1967 Fiscal Arrangements 
Act were extended (with a limit on annual increases in the federal contribution) with a consequent decline of interest in further research on alternatives for or implications of educational financing.

Reasons for the decline in interest and output can be summarized as follows: health and energy became more important public issues, government policy emphasis shifted from social services to supporting private sector improvements, the federal government's financial support for post-secondary education became so indirect that there seemed to be little reason for it to sponsor related research, and - partly as result and partly by coincidence - researchers moved to other countries, other employment, or to other research interests.

\section{What was Researched?}

The topics addressed by researchers in Canada were much the same as those treated elsewhere: resource allocation, and particularly returns to investment in higher education; productivity of educational institutions; alternative modes for financing institutions and students, together with the redistributive effects of these; some determinants of demand for places; and rationalization of the supply of places through educational and manpower planning.

Economic returns to post-secondary education in Canada were calculated (here one includes work prior to 1971) by Drummond, Podoluk, Wilkinson, Dodge, Stager, Mehmet; the Systems Research Group and the Economic Council of Canada. ${ }^{9}$ Mehmet (1977) up-dated his calculations using 1972 data and Holmes (1974) estimated the returns to education based on 1967 earnings data from the Statistics Canada Consumer Finance Survey. The rates of return were generally found to be higher than for either the United States or Great Britain, but one needs to be cautious in offering and testing hypotheses for these differences. Comay et al (1976) showed the effect of individuals' risk adversion and failure rates on private rates of return. The most recent work in this area, by Welland (1980), has been directed to refining the relationship between schooling and earnings.

Resource allocation has also been add ressed from the cost side alone (without taking into account the value of output) through a wide range of studies, from individual institutions to the national university system. Hettich's (1971) analysis of the productivity of Canadian universities for 1956 to 1968 shows the trend in real costs of university output measured as degrees and diplomas. Other cost studies - especially for provincial systems - were compared by P.-P. Proulx (1973) early in the decade when so many such studies were undertaken. The relative costs of alternative structures were also estimated, as in the report by Woods Gordon and Co. (1972) on a potential year-round operation of universities. Most institutions have developed planning models for internal resource allocation but few have been published; the model recently reported by Griew (1980) is an exception. Similarly, the Smith and Choudhry (1978) analysis of faculty salaries and producitivity is an example of work that ought to have appeared earlier and more frequently. 
The economic studies of demand for education have overlapped with sociological investigations of "accessibility" which are reported elsewhere. Crean's (1969) dissertation showed the importance of forgone earnings - a major component of education costs - in determining the demand for education, while Schaafsman's (1973) dissertation examined the effect on demand (or enrolment) of several socio-economic variables as reported in the 1961 census. Handa and Skolnik (1972) received a number of American and Canadian reports on demand - emphasizing the estimated elasticity coefficients for price (or tuition fee) and family income. Prokash (1976) related his study of demand to the intergovernmental arrangements for financing post-secondary education. Dodge and Swan (1971) reported a survey of Queen's University students which showed considerable differences among students in the accuracy of the information on which their educational decisions were based. Meltz's (1971) historical series on degrees granted, by field of study, shows how the composition of demand for university education has changed in the postwar period.

Much less effort was directed to research on the redistributive effects of educational finance, despite the political emphasis on income redistribution in the 1960s. The interprovincial redistributive effects of the 1967 fiscal transfers arrangement were reported both by Stager (1971) and by the Economic Council (1971). More recently, interpersonal redistribution was analyzed by Crean (1975), Buttrick (1977), and Mehmet (1978).

Alternative arrangements for financing higher education have received proportionately more attention than in the United States or the United Kingdom due to the continuing dilemmà of federal responsibility for economic development and regional equity and the provincial responsibility for education. Graham and Cameron $(1971,1973)$ have carefully documented the implications of the 1967 1977 fiscal arrangements including equalization payments while Leslie (1980) and Davenport (1981) have examined the more recent Established Programs Financing. Little attention has been directed to alternative tuition fee policies with the exception of Crowley's (1973) argument for free tuition - but an important paper on fee levels and differentials by Rosenbluth and Scott (1979) is to be published soon. Variations on student loans and grants have appeared frequently, particularly in the reports of provincial commissions. Cook and Stager (1971) published the simulated results of an income-contingent loan repayment scheme and West (1975) evaluated the Canada Student Loan Plan and its alternatives.

The relationship between education and manpower planning is open to many alternative approaches and models. Some of the difficulties and shortcomings have been described by Sewell (1972), Holland and Skolnick (1975), and Stager and Meltz (1977) and others, but fundamental analysis has been lacking. Various surveys of graduates - for example, by Harvey (1972) and by Statistics Canada (Clark \& Zsigmond, 1981) - have recorded the occupational destination of these graduates but the models required for analysis and policy still lack either the demand or supply side of the market. The Ministry of State for Science and Tech- 
nology (1980) and the Technical Council have used the Economic Council's CANDIDE model to generate demand estimates, but there are no complementary supply equations which take relative salaries into account. Von Zur-Muehlen (1978) has produced several papers - especially on doctoral graduates and on graduates of business programs - presenting data on the numbers and characteristics of persons involved but almost no alanytical work has been done on these and other data available from Statistics Canada. The richest data set of this kind was the 1973 survey of Highly Qualified Manpower based on the 1971 census respondents who had a university degree. Although Ahamad et al (1979) did preliminary analytical work on this data set, it has not been fully analyzed.

\section{Current Work}

Much of the current research is being done by educational institutions and provincial governments, with emphasis on the flow of persons through the system. This includes the development of models to forecast enrolments according to program or faculty, institution, and province. With the dip in post-secondary enrolments in 1972 and the continuing financial squeeze on institutions, educational administrators recognized the inadequacy of their enrolment models to forecast cyclical changes. It also became necessary to survey the employment experience of graduates - both to counteract the popular notion of high unemployment among graduates and to increase the data for enrolment forecasts on the (correct) assumption that prospective students monitored the graduates' labour market.

Another recent research innovation has been an analysis of the economic impact of educational institutions on their geographical communities (for example, the universities of Calgary, Manitoba, and Victoria). Institutions have also continued to develop their micro-planning capability using computer-based models of resource allocation within faculties and other divisions of a university. In general, however, current research activities tend to be more descriptive and less analytical than the work done a decade ago, or to repeat the earlier work with a localized data set.

\section{Looking Forward}

Even a modest menu for research efforts in the next decade would include several topics. But first, we need a method for making survey data and empirical analyses more widely known and more readily available. This would include the work of provincial government agencies, task forces, university planning offices, and institutional and faculty organizations. An inexpensive newsletter would suffice. This would not replace the AUCC Research Inventory or Selected Bibliography or reports in the AUCC and CAUT bulletins; rather, it would provide prompt, regular, brief reports on current publications. The CJHE might also include short notes on recent reports and annotated listings of articles published in other journals.

Important research topics for the 1980s arise both from questions generated by earlier research and from the new circumstances and problems requiring 
rational policy responses. For some of the unanswered questions in the economics of higher education, it is useful to refer to a review of human capital theory by Mark Blaug, a major contributor to this field. ${ }^{10}$ Blaug notes two related areas where the published research falls short: the demand for education, and the contribution of education to earnings differentials. These both are basic to an understanding of how and why employers use schooling credentials in hiring, promotion, and remuneration.

On the matter of demand for education, Blaug notes that

... it is surprising how little attention has actually been devoted to an explanation of the private demand for schooling. . . even now [1976] the demand for education remains a curiously neglected subject in the vast empirical literature exemplifying the human-capital approach. ${ }^{11}$

The private demand for education as an investment good is a primary component of manpower forecasting models:

...the problem of developing a satisfactory model of the American labor market for engineers, not to mention the demand for engineering as a field of study, remains unresolved. ${ }^{12}$

On the matter of schooling as a determinant of earnings differentials, Blaug states bluntly:

After ten years of work on earnings functions, all we have is
a dim light at the end of a tunnel: ... the fact remains that no
one has so far succeeded in specifying and testing the simul-
taneous demand and supply equations that generate the
earnings function, without which empirical work on earnings
function amounts to little more than trying to walk on one
leg.

An important development of the past decade was the hypothesis that schooling added little to one's cognitive skills. Rather, education was seen as a sorting or screening mechanism to identify persons who were most able to acquire the cognitive skills provided by employers. This screening or credentialism hypothesis is also described succinctly by Blaug:

The employer is ... faced with a selection problem: given the difficulties of accurately predicting the future performance of job applicants, he is tempted to treat educational qualifications as a screening device to distinguish new workers in terms of ability, achievement, motivation, and possibly family origins. . The contribution of education to economic growth, therefore, is simple that of providing a selection device for employers, and the way is now open to consider the question of whether formal schooling is indeed the most efficient selection mechanism that we could design for that purpose. ${ }^{14}$

One of Blaug's concluding comments is a simple, powerful challenge to inter- 
disciplinary research in higher education: "...the question is not whether schooling explains earnings, but rather why it does." 15

Future research in the economics of higher education ought to emphasize the link between education and earnings. There is still much to be done, in fundamental research on the acquisition and substitutability of skills, on the determinants of employment income, and on the linkages between these factors and individual career decisions, public policy decisions on provision of post-secondary places, and the development of alternative training and/or screening mechanisms.

\section{NOTES}

1. This quotation is part of economists' folk-lore - usually attributed to Jacob Viner but with no apparent source.

2. This is not a Canadian journal but is the journal devoted to higher education in which economists are most likely to seek publication.

3. Compare the current research reported in the AUCC Inventory for any year with the published work in the following few years.

4. See Edward F. Denison. The Sources of Economic Growth in the U.S. and the Alternatives Before Us, New York: Committee for Economic Development, 1962; T.W. Schultz. Investment in Human Capital, American Economic Review, 1961 LI(1) 1-17; Gary S. Becker. Human Capital: A Theoretical and Empirical Analysis. Princeton: Princeton University Press, 1964.

5. See for example, Paul Taubman and Terence Wales. Education as an Investment and a Screening Device, in F.T. Juster (ed.) Education, Income, and Human Behavior, New York: McGraw-Hill, 1975, 95-122.

6. See, for example, Jacob Mincer. Schooling, Experience, and Earnings. New York: National Bureau of Economic Research, 1974.

7. See items in the Bibliography by Graham and Cameron, Downey, Peitchinis, Tu, Stager, and Sheehan. (Proulx was published in French.)

8. See the Eighth Annual Review (1972) of the Economic Council of Canada; also papers in the collection edited by Sylvia Ostry (1972), as director of the Economic Council.

9. A summary of these studies is in Stager's paper on resource allocation in Sylvia Ostry (ed.), Canadian Higher Education in the Seventies.

10. Mark Blaug. Human Capital Theory: A Slightly-Jaundiced Survey, Journal of Economic Literature, 1976, 14 (3), 827-955.

11. Ibid., p. 831.

12. Ibid., p. 836 .

13. Ibid., p. 845 .

14. Ibid., p. 846 .

15. Ibid., p. 848.

\section{REFERENCES}

Ahamad, Bashir, et al. Degree-holders in Canada: An Analysis of the Highly Qualified Manpower Survey of 1973. Ottawa: Secretary of State, 1979.

Alberta. Task Force to Review Students' Contributions to the Costs of Post-secondary Education. Report. Edmonton: Queen's Printer, 1978. 
Boyd, A.D. and A.C. Gross. Education and Jobs. Special Study No. 28, Science Council of Canada. Ottawa: Information Canada, 1973.

Buttrick, John A. Who Goes to University from Toronto? Working Paper No. 1/77. Toronto: Ontario Economic Council, 1977.

Buttrick, John A. Educational Problems in Ontario and Some Policy Options, Occ. Paper 4. Toronto: Ontario Economic Council, 1977.

Canada, Ministry of State for Science and Technology. Research Manpower Requirements Arising from Accelerated Expenditures on $R \& D$. (working paper) April 1980.

Canada, Ministry of State for Science and Technology. Supply of Research Trained Personnel - A Regional Analysis. (working paper) May 1980.

Clark, W. and Z. Zsigmond. Job Market Reality For Postsecondary Graduates. Ottawa: Supply and Services Canada, 1981.

Colvin, J.A. Higher education and manpower needs. Canadian Journal of Higher Education, $1979,9(2), 87-94$.

Cook, Gail C.A. and Stager, David. Student Aid: A Proposal and Its Implications. Canadian Tax Journal, 1971, XIX (6), 558-564.

Comay, Y., Melnik, A. and Pollatscheek, M.A. Dropout risks, option values, and returns to investment in schooling. Canadian Journal of Economics, 1976, Vol. 9(1), 45-56.

Commission of Inquiry on Educational Leave and Productivity. Report: Education and Working Canadians. Ottawa: Labour Canada, 1979.

Crean, John F. The Demand for Education in Canada. Unpublished Ph.D. thesis, London School of Economics, London, 1969.

Crean, John F. Forgone earnings and the demand for education: some empirical evidence. Canadian Journal of Economics, 1973, VI (1), 23-42.

Crean, John F. The income redistributive effects of public spending on higher education. Journal of Human Resources, 1975, 10(1), 116-123.

Crowley, Ronald W. Towards free post-secondary education. Journal of Canadian Studies, 1973, VIII(3) 43-57.

Davenport, Paul. "Federal Funding of University Education," in D.M. Nowlan and Richard Bellair (eds.) Financing Canadian Universities: For Whom? By Whom? Toronto: O.I.S.E. Press, for the Institute for Policy Analysis and the Canadian Association of University Teachers, 1981.

Downey, Lorne. Alternative Methods of Financing Post-Secondary Education. Study No. 5. Toronto: Council of Ministers of Education, Canada, 1971.

Dodge, David A. Occupational Wage Differentials, Occupational Licensing, and Returns to Investment in Higher Education: An Exploratory Analysis, in Sylvia Ostry (ed.) Canadian Higher Education in the Seventies. Ottawa,: Information Canada, 1972, 133-176.

Dodge, David A. Returns to Investment in University Training: The Case of Canadian Accountants, Engineers and Scientists. Kingston: Industrial Relations Centre, Queen's University, 1972.

Dodge, David A. and Swan, Neil, M. Factors Influencing Career Choices of Students. disc. paper \# 48, Kingston: Queen's University, Institute for Economic Research, 1971.

Dodge, David A. and David Stager. Economic returns to graduate study in science, engineering, and business. Canadian Journal of Economics, 1972, V(2), 182-188.

Economic Council of Canada. Eighth Annual Review: Design for Decision-Making. Ottawa: Information Canada, 1971, Ch. 9.

Federal-Provincial Task Force on Student Assistance. Report. Ottawa: Supply and Services Canada, 1981. 
Graham, John F. and Cameron, J.R. Federal Participation in the Financing of Post-Secondary Education in Canada, 1967-1970. Study No. 3. Toronto: Council of Ministers of Education, Canada, 1971.

Graham, John F. and Cameron, J.R. Equalization in federal support for post-secondary education. Canadian Public Administration, 1973, 16, 139-143.

Griew, Stephen. A Model for the allocation and utilization of academic staff resources. Canadian Journal of Higher Education, 1980, X(2), 73-84.

Handa, M.L. and M.L. Skolnik. Empirical Analysis of the Demand for Education in Canada, in Sylvia Ostry (ed.) Canadian Higher Education in the Seventies, Ottawa: Information Canada, 1972, 5-44.

Handa, M.L. and Skolnik, M.L. Empirical Analysis of the Demand for Education in Canada. university education in Ontario: some empirical results. Higher Education, 1975, 4(1) 27-44.

Hartle, D.G. Financing of Higher Education in the 70's: A viewpoint from Ottawa. Stoa, 1973, III(2), 113-140.

Harvey, E.B. Education and employment of arts and science graduates: the last decade in Ontario. Toronto: Queen's Printer, 1972.

Hettich, Walter. Consumption Benefits from Education, in Sylvia Ostry (ed.) Canadian Higher Education in the Seventies. Ottawa: Information Canada, 1972, 177-198.

Hettich, Walter. Expenditure, Output and Productivity in Canadian University Education, Special Study No. 14, Economic Council of Canada. Ottawa: Information Canada, 1971.

Hettich, Walter. Why Distribution is Important: An Examination of Equity and Efficiency Criteria in Benefit-Cost Analysis. Special Study No. 19, Economic Council of Canada. Ottawa: Information Canada, 1971.

Holland, John W. and Skolnik, Michael, L. Public Policy and Manpower Development. Toronto: Ontario Institute for Studies in Education, 1975.

Holland, John W. et al. Manpower Forecasting and Educational Policy. Toronto Queen's Printer, 1972.

Holmes, R.A. Economic Returns to Education in Canada. (No.13-556). Ottawa: Information Canada, 1974.

Leslie, Peter M. Canadian Universities, 1980 and Beyond. AUCC Policy Study No. 3. Ottawa: Association of Universities and Colleges of Canada, 1980.

Manitoba. Task Force on Post-Secondary Education in Manitoba, Report. (no publisher, no date - 1973?)

Mehmet, Ozay. Economic Returns on Human Capital Formation in Canadian University Education, 1961 to 1972. Relations Industrielles/Industrial Relations, 1977, 32(3), 321-339.

Mehmet, Ozay. The Ontario university system as weal th-creator: who benefits? who pays? Canadian Journal of Higher Education, 1979, 9(3), 43-51.

Mehmet, Ozay. Who Benefits from the Ontario University System: A Benefit-Cost Analysis by Income Groups. Occ. Paper 7. Toronto: Ontario Economic Council, 1978.

Meltz, Noah M. Patterns of University Education in Ontario, Canada, and U.S. by field of study, 1950-51 to 1980-81, Toronto: Institute for Policy Analysis, University of Toronto, 1971.

Murthy, K.S.R. and E.B. Harvey. Supply of and Demand for Accounting Professionals in Canada.

Nova Scotia, Royal Commission on Education, Public Services and Provincial-Municipal Relations. Report, Vol. III, Part K. Halifax: Queen's Printer, 1974. 
Ostry, Sylvia (ed.) Canadian Higher Education in the Seventies. Ottawa: Information Canada, 1972.

Ostry, Sylvia (ed.) and Mahmood Zaidi. LabourEconomics in Canada (third edition) Toronto: Macmillan, 1979.

Peitchinis, S.G. Financing Post-secondary Education in Canada. Toronto: Council of Ministers of Education, 1971.

Picot, W.G. The Changing Education Profile of Canadians, 1961 to 2000. Ottawa: Supply and Services Canada, 1980.

Porter, Marion R., John Porter, Bernard Blishen. Does Money Matter? Prospects for Higher Education. Toronto: York University, Institute for Behavioral Research, 1973.

Prokash, B. The demand for and financing of higher education in Canada, Ph.D. dissertation, University of Toronto (O.I.S.E.), 1976.

Proulx, Pierre-Paul. Cost studies in post-secondary education - Canada, Stoa, 1973, III(1), 5-16.

Rosenbluth, G. and Scott, A.D. The Economics of Student Fees, Disc. paper 79-22, Vancouver: University of British Columbia, 1979.

Ross, J. Gordon. A Little Less of the 'Who Pays? .. A Little More of the 'What For? ... Stoa, 1973, III (2), 141-149.

Schaafsma, J. The consumption and investment aspects of the demand for education, Journal of Human Resources, 1976, XI(2), 233-242.

Schrank, Wm. E. Sex discrimination in faculty salaries: a case study, Canadian Journal of Economics, 1977, X(3), 411433.

Sewell, David. Educational Planning Models and the Relationship Between Education and Occupation, in Sylvia Ostry (ed.) Canadian Higher Education in the Seventies. Ottawa: Information Canada, 1972, 45-74.

Sheehan, Bernard S. Federal Participation in the Financing of Research and Graduate Studies, 1966-1970, Study No. 4. Toronto: Council of Ministers of Education, Canada, 1971.

Siddiqui, M.F.U. Manpower information systems for educational planning, Ph.D. dissertation, University of Toronto (O.I.S.E.), 1974.

Skolnik, M.L. and Gillian Bryce. Some Economic Aspects of the Relationship Between Education and Employment of Technicians and Technologists in Ontario. Educational Planning Occ. Papers No. 5/71, Toronto. Ontario Institute for Studies in Education, 1971.

Smith, L.B. and Choudhry, Nanda, K. Academic salaries in Economics and the returns to academic productivity: a case study, Canadian Journal of Economics, 1978, $\mathrm{XI}(3), 603-613$.

Smith, Richard. Ontario University System Financing and Staffing Policies; A Quantitative Model for Policy Analysis, Canadian Journal of Higher Education, 1976, VI(3), 51-72.

Stager, David. Allocation of Resources in Canadian Education, in Sylvia Ostry (ed.) Canadian Higher Education in the Seventies. Ottawa: Information Canada, 1972, 199-238.

Stager, David. Economics of Continuing Education in the Universities, in Sylvia Ostry (ed.) Canadian Higher Education in the Seventies. Ottawa: Information Canada, 1972, 265-290.

Stager, David. Economic Issues in Canadian Education, in L.H. Officer and L.B. Smith (eds.) Issues in Canadian Economics, Toronto: McGraw-Hill Ryerson, 1974, pp. 311-320.

Stager, David. Federal Government Grants to Canadian Universities, 1951-1966, Canadian Historical Review, 1973, LIV (3), 287-297. 
Stager, David. The Evolution of Federal Government Involvement in the Financing of PostSecondary Education in Canada, 1867-1966. Study No. 1. Toronto: Council of Ministers of Education, Canada, 1971.

Stager, David. Provincial Income Transfers Through Federal Government Involvement in the Financing of Post-Secondary Education. Study No. 7. Toronto: Council of Ministers of Education, Canada, 1971.

Stager, David. The evolution of federal government financing of Canadian universities, Stoa, 1972, -1, 23-30.

Stager, David and Meltz, Noah. Manpower Planning in the Professions, in M.J. Trebilcock and Philip Slayton (eds.) The Professions and the Public, Toronto: University of Toronto Press, 1978, 165-176; reprinted in Canadian Journal of Higher Education, 1977, VII (3), 73-83.

Systems Research Group. Some Economics of Post-Secondary Education, A Critical Review. Toronto: Queen's Printer, 1972.

Systems Research Group. Financing Post-Secondary Education. Toronto: Queen's Printer, 1972.

Systems Research Group. Cost and Benefit Study of Post-Secondary Education in Ontario. Toronto: Queen's Printer, 1972.

Thibault, Claude. University Financing, in A. Gregor and K. Wilson (eds.) Issues in Higher Education. Winnipeg: University of Manitoba, 1979, 19-27.

Tu, Pierre N.V. Enrolment in and Costs of Post-Secondary Institutions in Canada, 1960 1980, Study No. 2, Toronto: Council of Ministers of Education, Canada, 1971.

Von Zur-Muehlen, Max. The Ph.D. Dilemma in Canada: A Case Study, in Sylvia Ostry (ed.) Canadian Higher Education in the Seventies. Ottawa: Information Canada, 1972, 75-132.

Von Zur-Muehlen, Max. The Ph.D. Dilemma in Canada Revisted, Canadian Journal of Higher Education, 1978, VIII (2), 49-92.

Welland, J.D. Schooling and ability as earnings complements, Canadian Joumal of Economics, 1980, XIII (2) 356-367.

West, E.G. The Yale Tuition Postponement Plan in the Mid-Seventies, Higher Education, $1976,5(2)$ 169-176.

West, E.G. "Differentiated Versus Equal Student Subsidies in Post-Secondary Education: A Current Canadian Dispute," Higher Education, 1974, 3 (1) 2542.

West, E.G. Student Loans: A Reappraisal, Working Paper No. 4/75. Toronto: Ontario Economic Council, 1975.

Woods, Gordon and Co. Organization of the Academic Year. Toronto: Queen's Printer, 1972.

Wright, D.T. The financing of post-secondary education: basic issues and distribution of costs, Canadian Public Administration, 1971, 14(4), 595-607.

Zaharchuk, T.M. Some aspects of planning for post-secondary vocational institutions: a case study, the Ryerson Polytechnical Institute, Ph.D. dissertation, University of Toronto (O.I.S.E.) 1971.

Zsigmond, Z. et al. Out of School - Into the Labour Force. Ottawa: Statistics Canada, 1978. 